\title{
EDITORIAL
}

\section{Cepa Tamarugal Originaria del desierto más árido del mundo}

\author{
Tamarugal Variety \\ Originating From the Driest Desert in the World
}

\section{Ingrid Poblete Quezada Académico Facultad de Recursos Naturales \\ Universidad Arturo Prat Iquique, Chile. ipoblete@unap.cl,}

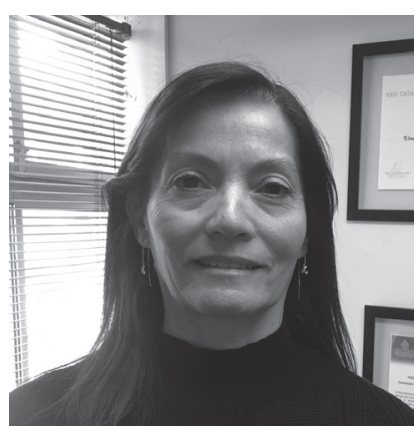

Ingrid Poblete Quezada

Academic Faculty of Natural

Resources

Universidad Arturo Prat

Iquique, Chile.

ipoblete@unap.cl
La vid fue introducida en América por los conquistadores españoles y los sacerdotes difundieron su cultivo con el fin de producir vino para celebrar la misa. En la zona norte de Chile, específicamente en el oasis de Pica y Matilla, su cultivo data de fines del siglo XVI y el término de la actividad vitivinícola se remonta al año 1937. Producto de esta historia, quedaron plantas olvidadas en el tiempo, en distintas localidades de la región, que lograron sobrevivir a las condiciones adversas del desierto más árido del mundo, el desierto de Atacama, caracterizado por suelos salinos, altas temperaturas en el día durante todo el año, y temperaturas nocturnas bajo cero durante el período invernal.

De estas plantas, en el año 2003 la Universidad Arturo Prat (UNAP) colectó material vegetal, el cual fue enraizado en la Estación Experimental Canchones, ubicada en la Pampa del Tamarugal, desierto de Atacama, y estableció un pequeño Jardín de Variedades. Se realizaron evaluaciones agronómicas y paralelamente comenzó el proceso de identificación molecular, de esta plantas. Estas pruebas se hicieron en el Instituto de Investigaciones Agropecuarias (INIA) La Platina, en Santiago de Chile, donde se identificó la cepa País. Posteriormente las muestras de ADN se enviaron al Instituto Madrileño de Investigación y Desarrollo Rural, Agrario y Alimentario (IMIDRA), de España, considerando que en su base de datos pudiesen tener cepas
The vine was introduced in America by the Spanish conquerors, and its cultivation was expanded by priests, to produce wine with which to celebrate mass. In the north of Chile, particularly in the oasis of Pica and Matilla, its cultivation dates from the end of the $16^{\text {th }}$ century, and the end of the viticulture activity dates back to 1937. As a result of history, plants were forgotten in time, in different localities of the region, which managed to survive the adverse conditions of the driest desert in the world, the Atacama desert, characterized by saline soils, high temperatures during the day throughout the year, and night temperatures below zero during the winter season.

Of these plants, Universidad Arturo Prat (UNAP) in 2003 collected plant material, which was rooted in the Canchones Experimental Station, located in the Pampa del Tamarugal and established a small "Variety Garden". Agronomic evaluations were carried out, and in parallel, a molecular identification process began, to determine the identity of the plants. This process was done in Chile, at the Agricultural Research Institute (INIA) La Platina, in Santiago, where the Country variety was identified. Subsequently, DNA samples were sent to Instituto Madrileño de Investigación y Desarrollo Rural, Agrario y Alimentario (IMIDRA), of Spain, considering that in their database they could have old varieties, 
antiguas, que contrastaran con las encontradas en el norte por la introducción efectuada en sus orígenes. Ellos identificaron una cepa tinta, Gros Colman, de Georgia, de la antigua Unión Soviética, y una rosada Ahmeur bou Ahmeur, argelina. Finalmente, quedaron dos genotipos blancos sin identificar, los cuales se enviaron al Instituto Nacional para la Investigación Agronómica (INRA) de Francia. Allí se identificó la cepa blanca de baya pequeña como Torrontés Riojano, de origen argentino. Quedó un genotipo blanco de baya grande que no se pudo identificar, después de haberlo contrastado con aproximadamente 7.000 genotipos.

Estos antecedentes se presentaron al Servicio Agrícola y Ganadero (SAG) en Santiago de Chile, con el objetivo de registrar la cepa. Para este organismo regulador, el antecedente molecular no es definitivo, por lo tanto, evalúa características ampelográficas, de acuerdo a las normas de la Unión Internacional para la Protección de las Obtenciones Vegetales (UPOV) y la Universidad aporta antecedentes previos. Este análisis busca corroborar que la cepa cumple con tres rasgos: estabilidad, homogeneidad e identidad. Así, después de dos temporadas agrícolas, confirmaron las características y en el año 2016 se obtuvo el registro definitivo, constituyéndose en la primera cepa vinífera chilena, bautizada con el nombre Tamarugal, originaria de la región de Tarapacá. La pregunta que viene ahora es: ¿Cómo surge esta cepa? Lo más probable es que provenga de una mutación de una cepa conocida y dadas las condiciones extremas de este desierto, provocó un cambio genético, transformándola en algo nuevo, que le permitió sobrevivir y adaptarse al medio donde está inserta. De este modo, presenta una brotación natural y su fruto recibe los beneficios del desierto, sin ser necesaria la aplicación de pesticidas.

Así surge entre las sales y el sol de la pampa la cepa Tamarugal, abriéndose paso en el desierto, coloreando de verde este suelo agreste, constituyéndose en un patrimonio genético invaluable, adaptada a las condiciones del desierto más árido del mundo, cuyos frutos dan origen en la actualidad al "Vino del Desierto", que vino del desierto para quedarse. which contrasted with those found in the north, by the introduction made in its origins. They identified a red variety, 'Gros Colman', from Georgia, from the former Soviet Union and a rose 'Ahmeur bou Ahmeur,' Algerian. Finally, two white genotypes remained unidentified. These were sent to the National Institute for Agronomic Research (INRA) of France, identifying the white variety of small berry as Torrontés Riojano, of Argentine origin. A white large berry genotype remained that could not be identified after having it contrasted with approximately 7,000 genotypes.

These antecedents were presented to Servicio Agrícola y Ganadero (SAG, Agricultural and Livestock Service) in Santiago, Chile, to register the variety. For this regulatory body, the molecular antecedent is not definitive. Therefore, it evaluates ampelographic characteristics, according to the rules of the Unión Internacional para la Protección de las Obtenciones Vegetales (International Union for the Protection of New Varieties of Plants $U P O V)$, with the University providing a previous background. This analysis seeks to corroborate that the variety meets three traits: stability, homogeneity, and identity. Thus, after two agricultural seasons, the characteristics were confirmed, and in 2016, the definitive registration was obtained, becoming the first Chilean wine variety, baptized with the name "Tamarugal", originally from the Tarapacá Region. The question that comes now is, how does this variety arise? Most likely, it comes from a mutation of a known variety, and given the extreme conditions of this desert, it caused a genetic change, which transformed it into something new, which allowed to survive and adapt to the conditions where it is inserted. In this way, it presents natural sprouting, and among other things, its fruit receives the benefits of the desert, the application of pesticides not being necessary.

Thus ascends between the salts and the sun of the Pampa' Tamarugal', making its way into the desert, coloring in green this rugged soil, becoming an invaluable genetic heritage, adapted to the most arid desert conditions in the world, whose fruits nowadays deliver the "Wine of the Desert" and arose from the desert to stay. 